KEIICHI KAWATE ${ }^{1}$

\title{
JAPANESE SELF-IMAGE IN OPPOSITION TO THE IDEA OF MODERN EUROPE AND THE RISE OF NATIONALISM IN JAPAN
}

\begin{abstract}
This paper attempts to explain the political and social context of the recent nationalistic trend in Japan in connection with the historical development of Japanese self-image. In Japanese modern history this self-image was formed in relation to modern Europe due to the fact that modern Japan first pursued the modernization of Europe and then tried to overtake it. The first goal of this paper is to provide an analysis of the formation process of Japanese self-image from a historical perspective. This process was divided in three phases which were connected with a changing understanding of Japanese modernity. It started with the criticism of the idea of European modernity in the 1940s and led, through the theory of modernization, to the development of the "theory of Japanese culture" (Nihonbunkaron) in the 1980s. The second goal of this paper is to conduct an analysis of the features of Japan's society, economy, and politics since the 1990s. The links between the collapse of the "Bubble Economy" and a rise in nationalism are shown. Although the article focuses on the domestic issues of Japan, it also reflects Japanese understanding of modern Europe and contributes to the understanding of cultural exchange between Europe and Japan.

Key words: Japanese self-image, Japanese modernity, European modernity, nationalism, Japanese history education
\end{abstract}

\section{INTRODUCTION}

At the end of 2006, under the government of Abe Shinzō (安倍晋三) one of the most important legal acts in Japan, namely the Fundamental Law of Education (教育基本法 Kyōiku Kihonhō), was revised. From the very

\footnotetext{
${ }^{1}$ Prof.; Tokyo Gakugei University; kawate@u-gakugei.ac.jp.
} 
beginning, a draft of the revision bill was vigorously opposed by people who feared the destruction of the democratic educational system. They were afraid that the revised law compelled students to develop a "patriotic spirit", a "love for Japanese culture" and "Japanese tradition" regarded by the opposition as the revival of the Imperial Rescript on Education (教育勅語 Kyōiku Chokugo) that formed the basis of the Japanese system of military education before the Second World War. Indeed, there is no doubt that Article 2 of the proposed law prescribed that virtues such as "love for Japanese culture" and "Japanese tradition" were an important competency to learn. In contemporary Japan, under Prime Minister Abe Shinzō, who returned to power in 2012, this political trend is continuously developing. It may be even said that during the Abe administration, ethnocentric nationalism has also been strengthened in Japan in reaction to globalization.

The aim of this article is to explain the political context of this recent trend in connection with the historical development of Japanese self-image in the modern age. In my opinion, a national self-image reflects political and social trends. However, it must be emphasized that the Japanese have tried to create such self-images with greater eagerness than other nations in modern times (Nihon Kagakusha Kaigi Shisō-Bunka Kenkyū linkai, 1991, pp. 35-88; Befu, 1997, pp. 36-67). In Japanese modern history this self-image was formed entirely in relation to developments in Europe, as modern Japan was pursuing the modernization of Europe and would try to overtake it at some point in the future. In other words, for the Japanese the concept of "modernity" was synonymous with the idea of modern Europe and, at the same time, an abstract goal to be achieved. Therefore, since the Meiji era, the Japanese have considered "modernity" as an object of discussion, and tried to understand it in the current situation and context. In such means, even though this article would explain the domestic issues of Japan, it also reflects Japanese understanding of modern Europe. Thus, the aim of the article is to contribute to understanding one of the aspects of cultural exchange between Europe and Japan.

\section{HISTORICAL PROCESS OF THE FORMATION OF JAPANESE SELF-IMAGES}

In order to investigate the reasons why nowadays conservative Japanese politicians, scholars or journalists intentionally emphasize the value of 
"Japanese culture" and "Japanese tradition", it is necessary to trace the historical process of the formation of Japanese self-image, and to analyze the character of its current mode of expression. For this purpose, it may be useful to look into the "theory of Japanese culture" (日本文化論 Nihonbunkaron), which appeared in the 1980s, in connection with its political and economic background. This theory has strongly influenced the creation of Japanese self-image. However, it must be emphasized that different Japanese self-images, such as those present in the "theory of Japanese culture", had emerged in modern Japanese history many times from the Meiji period (1868-1912) on.

One helpful source in analyzing the historical process of the formation of self-images is the article 「歴史学と『近代』」(Rekishigaku to "Kindai") written by the Japanese historian Nishikawa Masao (西川正雄). He looked for the answer as to how Japanese intellectuals have considered Japanese modernity starting with the Meiji period, especially in connection with the criticism of the idea of modern Europe (Nishikawa, 1987, pp. 149-175). Based on his analysis, I believe that three phases in the history of exchange between Europe and Japan are important for interpreting the process of the formation of the present Japanese self-image: the phase since 1942, which was the attempt at “overcoming Modernity" (近代の超克 Kindai no Chōkoku); the phase comprising the 1960s when the "Theory of Modernization" (近代化論 Kindaikaron) was developed; and the phase comprising the 1980s when the "Theory of Japanese culture" (日本文化論 Nihonbunkaron) was established and the idea of "Internationalization" (国際化 Kokusaika) was developed.

The first phase, namely that since 1942, has been described as an attempt at overcoming modernity (近代の超克 Kindai no Chōkoku). It began with a discussion about the Greater East Asia War (大東亜戦争 Daitōa Sensō) and advocacy of the "Japanese spirit", as well as Japanese modernity compared with that of the West (Sakai, 2010, pp. 3-30; Isomae, 2010, pp. 31-73). In this case, as the West was a synonym for modernity, the real goal was the creation of an original Japanese modernity through overcoming European models. The influential intellectuals of that time, such as philosophers, historians and the literary men of the Kyōto School (京都学派 Kyōto Gakuha), the members of the Literary Circle (文学界 Bungakukai) and the Japanese Romantic School (日本ロマン派 Nihon Roman $\mathrm{Ha}$ ) were involved in discussing the above ideas (Takeuchi, 1979, p. 288). These groups held a symposium on "Overcoming Modernity" on 23 and 
24 July 1942 in Kyōto, and published notes about the symposium, as well as some articles related to this topic in the September and October issues of the journal Literary Circles 『文学界』 (Kawakami, 1979, pp. 165-168; Kawakami \& Takeuchi, 1979, pp. 171-271).

During the symposium, representatives of the above-mentioned groups brought into question the deep acceptance of European modernity existing since the Meiji era. In their view, the Japanese people had decided to introduce the European idea of modernity during the Meiji era, because Europe seemed to have superiority in developing scientific techniques and their practical use (Nakamura, 1979, pp. 150ff). However, after Japanese society and policy began to face various crises from 1930 onwards, the above-mentioned groups of intellectuals attributed these problems to this concept of modernity and, as a result, organized the symposium in 1942 to overcome them (Kamei, 1979, pp. 4-17; Nishitani, 1979, pp. 32ff; Shimomura, 1979, pp. 112ff).

Certainly, their ideological point of view was strongly connected with the idea of the "Greater East Asia Co-Prosperity Sphere" (大東亜共栄圏 Daitōa Kyōeiken) and the Japanese invasive war in Asia. After the Second World War, the cultural theorist Takeuchi Yoshimi (竹内好) reconsidered the attempt at "Overcoming Modernity", and criticized the simple dichotomy between Japanese and European concepts of modernity. His idea was fully introduced in an article from 1979 entitled「近代の超克」“Kindai no Chōkoku" ("Overcoming Modernity"). In his view, these intellectuals should consider the crisis of Japanese modernity as an internal Japanese issue independent of European origins (Takeuchi, 1979, pp. 275-341).

The second phase started in the 1960s when the theory of modernization appeared. This was related to the American strategy during the Cold War and, in this context, the excellence of Japan and Japanese culture was advocated. The USA regarded the Japanese rapid economic growth as a successful model of modernization - a success which was hitherto an attribute of Western countries - and attempted to use the economic growth of Japanese society as an instrument that flaunted the superiority of a capitalistic state over socialism (Nishikawa, 1987, pp. 157-163). The theory of modernization provided an opportunity to make a positive evaluation of modern history. The positive evaluation of one's own history, the process of rapid economic growth and the recognition of Japan throughout the USA as a successful model of modernization, caused big changes in the formation of Japanese self-image. 
The third phase started in the 1980s and brought about the development of the theory of Japanese culture. At that time, a report entitled “The Age of Culture" (文化の時代 Bunka no jidai) was published by the Policy Research Group of the Prime Minister Ōhira Masayoshi (大平正芳) (大平総理の政策研究会 Ōhira Sōri no Seisaku Kenkyūkai) (Kawamura, 1982, pp. 143ff). This report expressed the idea that Japan had given up its own culture and traditions while it had been trying to pursue Western and industrial states as a model in the age of modernization, westernization, industrialization and economic growth. However, this situation has changed, in that since 1980s the time has come to reevaluate the characteristics of Japanese culture. Although at first glance, it looks similar to the period of activity described as the attempt at "Overcoming Modernity" from the 1940 s on, there are important differences. Firstly, it reflected the political and social situation of the 1980s, which was strongly connected to the rapid development of the Japanese economy since the 1960s. The economic power of Japan grew and the country overcame two "oil shocks" with the help of rationalization and Japanese-type management (日本型経営 Nihongata keiei) (Watanabe, 2004, pp. 98ff). As a result, Japan gained confidence as an economic power and no longer wished to regard Western countries as a model.

In 1982, Nakasone Yasuhiro (中曽根康弘) became prime minister and introduced neoliberal policies under the slogan of "The Total Settlement of Postwar Politics" (戦後政治の総決算 Sengo Seiji no Sōkkesan) (Watanabe, 2004, pp. 115ff). The theory of Japanese culture appeared under his government, together with the international strategy of Japanese capitalism. This theory was embodied in the establishment of the International Research Center for Japanese Studies (国際日本文化研究センタ Kokusai Nihon Bunka Kenkyū Sentā) in Kyōto. The first head of this Institute, Umehara Takeshi (梅原猛) had already developed the theory of Japanese culture in the 1970s, namely Nihonbunkaron. He proposed a concept based on contradictions between Japanese culture and European civilization and advocated the originality of Japanese culture (Umehara, 1976, pp. 51ff). However, the rough and conflict-based character of his theory was criticized by some researchers in Japan and overseas, especially, the historian Kano Masanao (鹿野政直), who critically summarized the features of Umehara's theory of Japanese culture in four points (Kano, 1988, pp. 234ff). The first concerned the process of Japanese strategic "Internationalization". According to Kano, the theory mistakenly emphasized the self-awareness of the 
Japanese nation to realize the concept of kokusaijin (国際人), which means "internationally-minded man" or "Japanese as a citizen of the world". This means that "Internationalization" and "emphasis on Japanese self-awareness" were two sides of the same coin. Secondly, it aimed to create the ideological future of Japan in the $21^{\text {st }}$ century in which the theory of Nihonbunkaron would play a strategic role. Thirdly, the theory gave superiority to the economic aspect of society. Umehara's theory too easily proposed Japanese society and "Japanese-type management" as a model for the world to follow based on the self-confidence of Japanese "success" and the result of being "an economic power". Fourthly, Umehara's theory tried to find the origin of Japanese culture as being far from the mythos of the Emperor (天皇 Tennō). This was in opposition to the former Japanese nationalistic theories in modern Japan that were mostly based on the mythos of the Japanese Emperor. Moreover, Umehara's theory attempted to emphasize the complex character of Japanese culture and its positive attitude toward the reception of foreign culture, in contrast with the former theories that emphasized Japanese national and cultural purity. However, the problem which Kano Masao noticed and criticized was the fact that while Umehara proposed the opening of Japanese culture to the world, he proposed at the same time the establishing of a nationalistic Japanese culture, one which should be an expression of Japanese national identity.

\section{JAPAN AFTER THE "THEORY OF JAPANESE CULTURE" (NIHONBUNKARON)}

As already mentioned, the "theory of Japanese culture" (Nihonbunkaron) appeared in connection with the self-confidence of conservative politicians and business groups. The Japanese economy, which by now had achieved its highest level of development, brought about an unusual level of speculation in real estate from the second half of the 1980s to the beginning of 1990s, known as the "Bubble Economy". During this time the superiority of Japanese-type economies was advocated. However, once the "Bubble Economy" collapsed, the situation of the Japanese economy changed completely. After the collapse, Japan's economy suffered from a long-term recession that was known as the "lost 10 years" or "lost 20 years". This new economic situation had also an influence on the discourse of the theory of Japanese culture that had drawn great attention in the 1980s. Therefore, 
I would like to investigate the impact of this new economic situation on the discourse of the theory of Japanese culture and how it has been related to ethnocentric nationalism since the 1990s.

If one attempts to clarify the reason why "culture" and "tradition" are so strongly emphasized in present-day Japan, it is necessary to analyze more concretely the Japanese political and social situation in the 1990s. Whereas it is obvious that the years 1989/1990 marked the beginning of a new epoch in modern world history, this time was also important for Japan. Emperor Hirohito (Showa Tennō 昭和天皇), who was the symbol of Japanese national identity, died in January 1989. The emperor's death and the resulting series of ceremonies involving the imperial family made a significant impression on Japanese society since emperor-based ideology was deep-rooted in society. It seems that the death of the charismatic Hirohito basically changed the political and social position of the emperor and his role in the discourse about Japanese culture and tradition (Watanabe, 1990, pp. 370-414).

On the other hand, the end of the Cold War and the expansion of the global market changed the Japanese position in American strategic thinking. Although the USA had not demanded a large share of military expenses from Japan during the Cold War, it changed this policy after that period. This was symbolically visible, especially during the Gulf War in 1990. Although the Japanese government paid a total of $\$ 11$ billion to the multinational forces at that time, Japan was not only praised, but also criticized for the fact that it had only contributed financially while not undertaking an appropriate military burden. Under the influence of this situation, the Japanese government and conservative politicians started to look to the overseas expansion of Japan's Self-Defense Forces. A way to ensure a military presence overseas was desirable for the Japanese multinational corporations which had started full-scale overseas expansion since the second half of the 1980s (Watanabe, 2007, pp. 289-329). Moreover, after the collapse of the "Bubble Economy", the Japanese economy fell into recession. However, the recession in 1990s had its own background, which the political scientist Watanabe Osamu (渡辺治) described as follows:

The system that supported Japanese economic development was fundamentally dependent on the policy of intervention by the state. The government implemented measures to redistribute the profit through the public works system under the control of the Liberal Democratic Party. The system included 
the working class organized into labor unions in particular companies. However, the system hindered the overseas expansion of Japanese corporations in 1990s and brought about the recession. During the rise of Asian countries, especially China, the Japanese economy required liberalization, rationalization, efficiency, and at last, conversion from Japanese-type management. (Watanabe, 2005, pp. 252ff)

In this way, Japanese society was confronted with great changes which exerted an influence on the creation of a Japanese self-image of that time. In this situation, the theory of Japanese culture, which from the 1980s represented pride in being Japanese, lost its significance rapidly. Instead of this, the trend of narrow-minded nationalism appeared.

The source of this new nationalistic trend was the fact that three former Korean “comfort women” (従軍叞安婦 jūgun ianfu) had brought a legal suit against the Japanese government in December 1991. The Japanese government did not accept the charge that the government and the army should share the responsibility for this crime against humanity. As a result, an apology was postponed by the Japanese government for over 50 years.

However, in early 1992, a Japanese historian, Yoshimi Yoshiaki (吉見義明), found hitherto unknown government documents. This newly found evidence made it clear that the Japanese military had played a direct role in setting up the "comfort stations". After that, the Japanese government reversed the official position and admitted that the government had played a crucial role in the system of providing "comfort women" (Yoshimi, 1995, pp. 5ff). On this occasion, it became finally possible not to erase the description of "comfort women" from the history textbooks of junior high schools by the Ministry of Education anymore. This was the fact which influenced Japanese education system, later becoming an important part of it.

Such condemnation of Japanese war crimes was opposed by the rightwing opposition, which aimed to ensure the revision of modern Japanese history. They denied the existence of the former Korean "comfort women", as well as "Nanjing Massacre", and perceived both as the "self-tormenting view of history" (自虐史観 jigyakushikan), one which exaggerates the dark side of history. The right-wing opposition persisted in promoting the necessity of emphasizing the achievements of modern Japan as an independent state, as well as the fact that the Japanese should have pride in their own history. They also justified former Japanese military operations as a struggle for the liberation of Asia. 
At the same time, the "revisionists" from the right-wing, who had declared the "neoliberal conception of history" (新自由主義史観 Shin Jiyūshugi Shikan), tried to change the description of history in the history textbooks for Japanese junior high schools. They organized a so-called “Japanese Society for History Textbook Reform” (新しい教科書をつくる会 Atarashii Kyōkasho wo Tsukuru Kai) in 1996 and wrote their own textbook. The textbook focused on the history of emperors and exaggerated their mythos to legitimize their rule. Moreover, while it covered numerous acts of "great persons" such as politicians or military commanders, the social history of ordinary people was left out. Thus, "Japanese history" and "Japanese culture" were glorified by the revisionists. It is significant that the Ministry of Education ultimately approved this textbook for classroom use after correcting many factual errors. Therefore, it has been used by some schools since 2001 (Gordon, 2003, p. 332). In consequence, the rightwing revisionist vision of history influences not only education but also the process of creating a Japanese self-image.

\section{TODAY'S JAPANESE NATIONALISM IN CONNECTION WITH POLITICAL, SOCIAL AND EDUCATIONAL BACKGROUND}

In this section, I would like to analyze the political, social and educational situation in which present-day conservative politicians and leading financiers advocate a vision of Japanese culture and tradition based on the new aggressive nationalism discussed above.

As I have already mentioned, the end of the year 2006 brought the revision of the Fundamental Law of Education. This law obligated all Japanese students to develop a "patriotic spirit" as well as a "love for Japanese culture and Japanese tradition". It was criticized because of its similarity to the former Imperial Rescript on Education, which was promulgated under the name of Emperor Meiji in October 1890 and had attached great importance to Confucian values such as "loyalty", "obedience" and "fellowship". It demanded the obedience to the Japanese state, the emperor and his ancestors. In this way, education supported Japanese militarism.

While many educators, scholars and journalists considered the revision of the Fundamental Law of Education only as a revival of the former Imperial Rescript on Education, it also had a second aim. The revision aimed to introduce the principle of competition into a Japanese education system 
that had supported the principle of equality among pupils for a long time. It was a tool to accomplish the strategy of the Japanese government to establish a science and technology-oriented nation, and to tighten control on education.

Even if the revision of the Fundamental Law of Education had been a strong desire of nationalistic politicians for a long time, it was remarkable that the government had never put this desire into practice until 2006. In that respect, it is important to analyze why the revision of the Fundamental Law of Education became an actual political issue at the beginning of the $21^{\text {st }}$ century. Even though the supporters of this revision were looking back to the former Imperial Rescript on Education in a nostalgic manner, we should not understand this revision only in a historical context as it was strongly connected to Japanese politics and the economic situation at the time.

The situation of Japanese society changed drastically after the recession in the 1990s. Japanese social awareness of a so-called "100 million total middle-class society" (一億総中流社会 ichioku sōchūryū shakai) had been already lost. According to an inquiry made by the Ministry of Education in 2005, the number of the elementary schoolchildren who were unable to pay their school lunch expenses reached 40,000 , while the total sum used to support them reached 200 million yen. In present-day Japan, the number of people who need an allowance from the government has rapidly increased, while at the same time this allowance was drastically cut. One serious problem is the increasing number of non-regular workers, especially among the young generation. The words like "freeter" (フリーター) or "NEET" (ニート) were coined to reflect such a situation in Japan. The word "freeter" was formed from the term "Freelance Arbeiter", and "NEET" from the expression "Not in Education, Employment or Training". An increase in the numbers of the poor and needy is a serious social problem (Honda, Naitō \& Gotō, 2006, pp. 16-20). As a result, the Japanese selfimage started to change speedily.

Simultaneously, this self-image is also connected to political changes in contemporary Japan. One example may be an attempt of the government to amend Article 9 of the constitution, which outlawed war as means of settling international disputes involving the state. However, this clause is inconsistent with the demand of the Japanese business community which may need military protection when Japanese companies expand into countries that are politically instable (Watanabe, 2005, pp. 170-193). In this situation, the question arises as to how this strategy supported by the Abe 
government would be related to the emphasis on Japanese culture and tradition. In order to answer this question, it is necessary to understand the emphasis of Japanese culture and tradition in a political and social context. Therefore, we can refer to a book Healing Nationalism 『癒しのナショ ナリズム』 (Iyashi no Nashonalizmu) written by the historical sociologist, Oguma Eiji (小熊英二) (Oguma \& Ueno, 2003, pp. 188-223). Having analyzed who had supported the revisionist movement since 1990s, in Oguma Eiji's view these people do not always assert their xenophobic nationalism clearly. The keyword of his concept of nationalism was "healing" (癒し), which can be summarized in the political context described below.

While Prime Minister Abe is known as a conservative politician, at the same time, he promotes a neo-liberal policy that had been continued since Prime Minister Koizumi Junichirō (小泉純一郎) under a slogan of “reform" (kaikaku 改革) (Watanabe, 2005, pp. 60-130). For instance, these policies included the "Relaxation of Economic Regulation or Protectionism", such as the privatization of Japan Post, the "Reduction of Social Security Expenses", and the "Hard-fought Free Competitive Market". As a result, a society with a largest gap between rich and poor in Japanese history appeared. However, there is no contradiction between neo-liberal economic reform and conservative education system reform that not only emphasizes culture and tradition but also reinforces state control. Since it was impossible to mitigate the damage by social policies or welfare, nationalism was needed to conceal a divided Japanese society. This healing nationalism could play the "healing" role through creating a feeling of identity with the state for a now-divided Japanese society. For example, when the first Abe cabinet was formed in 2006, it promoted Japan as a "beautiful state" (美しい国 utsukushii kuni), whose "beauty" is based on having arisen from Japanese culture and traditions in connection with the rule of the emperor. This idea was incorporated into the Japanese curriculum starting already in junior high schools. Thus, the danger of the development of nationalistic way of thinking and creating a strongly nationalistic Japanese self-image appeared. As already mentioned, Abe's idea has been criticized by Umehara Takeshi, among others. Even though he was an advocate of the vision of Japanese culture which is close to Abe's idea of Japan as a "beautiful state" based on an emphasis on Japanese culture and tradition, he pointed out that amending the constitution would strengthen the idea of a militant Japan.

Summing up, there is almost no other nation like the Japanese who try to paint their own portrait in such a positive light. In other words, Japanese 
society is sensitive in terms of its self-image and looks like being psychologically insecure in relation to Western countries. This article has tried to show this through analyzing its development during three phases. It concludes that in the last phase, since the collapse of the "Bubble Economy" in the 1990s, exclusivist nationalism has started to grow. However, in my opinion, Japanese society should not express a narcissistic self-love, but look for an objective self-portrait. Thus, in the face of Japanese exclusive nationalism it is necessary to rethink the value of the European concept of modernity.

\section{BIBLIOGRAPHY}

Befu, H. (1997). ハルミ・ベフ:『増補新版イデオロギーとしての日本文化論』 (Zōhoban Ideologi toshite no Nihonbunkaron). 思想の科学社, 東京 (Tōkyō: Shisō no Kagakusha).

Gordon, A. (2003). A Modern History of Japan: From Tokugawa Times to the Present. New York: Oxford University Press.

Honda, Y., Naitō, A., \& Gotō, K. (2006). 本田由紀/内藤朝雄 / 後藤和智: 『「二ート」って言う な!』(“Nīto” tte iuna!). 光文社, 東京 (Tōkyō: Kōbunsha).

Isomae, J. (2010). 磯前順一: 『『近代の超克』と京都学派一近代性·帝国·普遍性」(“Kindai no Chōkoku" to Kyōto Gakuha). In 酒井直樹 / 磯前順一 (N. Sakai \& J. Isomae), 『「近代 の超克」と京都学派』(“Kindai no Chōkoku” to Kyōto Gakuha) (pp. 31-73). 以文社, 東京 (Tōkyō: Ibunsha).

Kamei, K. (1979). 亀井勝一郎:「現代精神に関する覚書」(Gendai Seishin ni kansuru Oboegaki). In 河上徹太郎/竹内好 (T. Kawakami \& Y. Takeuchi), 『近代の超克』 (Kindai no Chōkoku) (pp. 4-17). 冨山房, 東京 (Tōkyō: Fuzambo).

Kano, M. (1988). 鹿野政直:『「鳥島」は入っているか』(“Torishima” wa haitteiruka). 岩波書店, 東京 (Tōkyō: Iwanami Shoten).

Kawakami, T. (1979). 河上徹太郎: 『『近代の超克』結語」(“Kindai no Chōkoku” Ketsugo). In 河上徹太郎/竹内好 (T. Kawakami \& Y. Takeuchi), 『近代の超克』 (Kindai no Chōkoku) (pp. 165-168). 富山房, 東京 (Tōkyō: Fuzambo).

Kawakami, T., \& Takeuchi, Y. (1979). 河上徹太郎/竹内好: 『近代の超克』 (Kindai no Chōkoku). 冨山房, 東京 (Tōkyō: Fuzambo).

Kawamura, N. (1982). 河村望: 『日本文化論の周辺』(Nihonbunkaron no Shūhen). 人間の科 学社, 東京 (Tōkyō: Ningen no Kagakusha).

Nakamura, M. (1979). 中村光夫: 『近代』への疑惑」("Kindai" he no Giwaku). In 河上徹太郎 / 竹内好 (T. Kawakami \& Y. Takeuchi), 『近代の超克』(Kindai no Chōkoku). 富山房, 東京 (Tōkyō: Fuzambo).

Nihon Kagakusha Kaigi Shisō-Bunka Kenkyū linkai (1991). 日本科学者会議思想·文化研究委 員会編: 『日本文化論批判』(Nihonbunkaron Hihan). 水曜社, 東京 (Tōkyō: Suiyōsha).

Nishikawa, M. (1987). 西川正雄: 「歴史学と『近代』」 (Rekishigaku to “Kindai”). In 西川 正雄 /小谷注之 (M. Nishikawa \& H. Kotani), 『現代歴史学入門』(Gendai Rekishigaku Nyūmon) (pp. 149-175). 東京大学出版会, 東京 (Tōkyō: Tōkyō Daigaku Shuppankai).

Nishitani, K. (1979). 西谷啓治:「『近代の超克』私論」(“Kindai no Chōkoku” Shiron). In 河上 徹太郎/竹内好 (T. Kawakami \& Y. Takeuchi), 『近代の超克』(Kindai no Chōkoku) (pp. 1837). 畐山房, 東京 (Tōkyō: Fuzambo). 
Oguma, E., \& Ueno, Y. (2003). 小熊英二·上野陽子: 『癒しのナショナリズム』 (lyashi no Nashonarizumu). 慶應義塾大学出版会, 東京 (Tōkyō: Keiō Gijuku Daigaku Shuppankai).

Sakai, N. (2010). 酒井直樹: 「序 パックス・アメリカーナの下での京都学派の哲学」(Jo Pakkus Amerikāna no moto deno Kyōto Gakuha no Tetsugaku). In 酒井直樹/磯前順一 (N. Sakai \& J. Isomae), 『「近代の超克」と京都学派』 (“Kindai no Chōkoku” to Kyōto Gakuha) (pp. 3-28). 以文社, 東京 (Tōkyō: Ibunsha).

Shimomura, T. (1979). 下村寅太郎: 「近代の超克の方向」 (Kindai no Chōkoku no Hōkō). In 河上徹太郎/竹内好 (T. Kawakami \& Y. Takeuchi), 『近代の超克』(Kindai no Chōkoku) (pp. 112-117). 冨山房, 東京 (Tōkyō: Fuzambo).

Takeuchi, Y. (1979). 竹内好: 「近代の超克」 (Kindai no Chōkoku). In 河上徹太郎/竹内好 (T. Kawakami \& Y. Takeuchi), 『近代の超克』(Kindai no Chōkoku) (pp. 273-341). 冨山房, 東京 (Tōkyō: Fuzambo).

Umehara, T. (1976). 梅原猛: 『日本文化論』(Nihonbunkaron). 講談社, 東京 (Tōkyō: Kōdansha).

Watanabe, O. (1990). 渡辺治: 『戦後政治史の中の天皇制』 (Sengo seijishi no naka no Tennōsei). 青木書店, 東京 (Tōkyō: Aoki Shoten).

Watanabe, O. (2004). 渡辺治: 「高度経済成長と企業社会」(Kōdo Keizai Seichō to Kigyō Shakai). In 渡辺治 (編) (O. Watanabe [Ed.]), 『高度経済成長と企業社会』 (Kōdo Keizai Seichō to Kigyō Shakai) (pp. 7-126). 吉川弘文館, 東京 (Tōkyō: Yoshikawa Kōbunkan).

Watanabe, O. (2005). 渡辺治: 『構造改革政治の時代: 小泉政権論』 (Kōzō Kaikaku Seiji no Jidai: Koizumi Seiken Ron). 花伝社, 東京 (Tōkyō: Kadensha).

Watanabe, O. (2007). 渡辺治:「付録: 日本の新自由主義」(Furoku: Nihon no Shinjiyūshugi). In デヴィッド・ハーヴェイ (D. Harvey), 『新自由主義』(Shinjiyūshugi). 作品社, 東京 (Tōkyō: Sakuhinsha).

Yoshimi, Y. (1995). 吉見義明: 『従軍慰安婦』(Jūgun lanfu). 岩波書店, 東京 (Tōkyō: Iwanami Shoten). 